\title{
METHODOLOGICAL PRINCIPLES OF WASTE HAZARDOUSNESS CLASSIFICATION
}

\author{
L. Poviakel, O. Vasetska, G. Petrashenko, O. Bobylova, V. Krivenchuk, O. Zubko \\ L.I. Medved's Research Centre of Preventive Toxicology, Food and Chemical Safety, \\ Ministry of Health, Ukraine (State Enterprise), Kyiv, Ukraine
}

ABSTRACT. The Aim of the Research. Clarification of the problem of the negative impact of waste on the environment and public health. They appear from the waste formation and at all stages of its handling.

Materials and Methods. One of the priority areas of approximation to the requirements of the European Union in waste management is the harmonization of modern Ukrainian legislation with European standards, adaptation of regulations, including the classification of waste according to the degree of danger. The article provides a comparative analysis of the legal framework for waste hazardousness assessment currently existing in Ukraine with WHO recommendations and EU Directives. The methodological principles of classification of waste according to a degree of hazardousness are substantiated and recommended for implementation.

Results and Conclusions. It is scientifically proven that the assignment of waste to a certain classification category of hazard should be based not only on quantitative calculations of chemical composition and toxicity of constituent ingredients that are part of the waste, but also on experimental testing of samples using alternative methods.

Key Words: waste, EU Directive, classification, biological testing, toxicity, hazard, alternative methods.

Introduction. During the last $10-15$ years there has been a steady trend in adverse effects of various environmental factors on human health, leading to negative effects - health deterioration, increased morbidity, and, sometimes, mortality. There is no doubt that the contaminated environment is the media which impairs the health and well-being of people who are weakened or have chronic diseases. Today we will talk about human waste, industrial waste, agricultural technology waste and others - they are among the most dangerous pollutants. In the media, from the tribunes of scientific and environmental forums the words "Curse of our time" - that's what the waste (the consequences of human management) is called, are heard more and more often $[1,2]$.

The Aim of the Research. Clarification of the problem of the negative impact of waste on the environment and public health. They appear from the waste formation and at all stages of its handling.

Materials and Methods. One of the priority areas of approximation to the requirements of the European Union in waste management is the harmonization of modern Ukrainian legislation with European standards, adaptation of regulations, including the classification of waste according to the degree of danger. The article provides a comparative analysis of the legal framework for waste hazardousness assessment currently existing in Ukraine with
WHO recommendations and EU Directives. The methodological principles of classification of waste according to a degree of hazardousness are substantiated and recommended for implementation.

Results.According to the State Statistics Service in Ukraine today:

- There is about 300 tons of waste per each inhabitant, and this amount is constantly increasing;

- 13 billion tons of waste have been accumulated;

- There are, by far incomplete data, about 35000 illegal dumps.

These are eloquent figures, so the whole world has started to look for a solution for this problem, the urgency of which is out of the question. It is obvious.

In the EU the waste management law is presented in ten directives and other regulations [3]:

- Directive 2008/98/EC on waste (Waste Framework Directive)

- Directive 1999/31/EC on the landfile of waste

- Directive 2006/21/EC on the management of waste from extractive industries

- Directive 96/59/EC on the disposal of polychlorinated biphenyls and polychlorinated terphenyls (PCB/PCT)

- Directive 94/62/EC on packaging and packaging waste 
- Directive 91/689/EC on hazardous waste

- Directive 94/67/EC on the incineration of hazardous waste

- Directive 2012/19/EC on waste electrical and electronic equipment

- Directive 2006/66/EC on batteries and accumulators and waste batteries and accumulators

- Stockholm Convention on POPs (ratified in Ukraine on 18.04.2007 № 949-V)

- Basel Convention on the Control of Transboundary Movements of Hazardous Wastes and their Disposal (Ukraine's Law №803-XIV from 07.01.99).

- Rotterdam Convention on the Prior Informed Consent Procedure for Certain Hazardous Chemicals and Pesticides in International Trade (entered into force in Ukraine on December, 12019 ).

In September 2014 the directive of the Cabinet of Ministers of Ukraine "On the implementation of the EU-Ukraine association agreement" approved a road map for the implementation of EU Directives, developed and submitted to the Cabinet of Ministers of Ukraine drafts of regulations for the implementation of the provisions of Directives that are specified in the Annex to the Agreement [4].

Ukraine, first of all, should implement the following Directives:

- Directive 2008/98/EC of the European Parliament and the European Council "On waste and repealing certain Directives" (Framework) of 19 November 2008, which provides for tightening of requirements for waste collection and recycling. Based on the proposals of the European Commission, the following requirements were set: re-use and recycling of $65 \%$ of total waste and $10 \%$ of permissible waste disposal in the European Union;

- Directive 1999/31/EC on the landfill of waste - waste management policy provides that in the future within the Community only safe and controlled activities on waste disposal should be performed; whereas, in accordance with the "polluter pays" principle, any damage to the environment resulting from the disposal of waste must be taken into account;

- Directive 2006/21/EC on the management of waste from extractive industries sets out recommendations for the prevention and minimization of risks that may arise from the generation and disposal of extractive waste.

The terms of implementation of these directives range from 2 to $5-6$ years.

The EU Directives set out the basic principles for the management of waste and its individual fractions. The base point for all directions is the classification of waste according to hazard degree that is necessary to:

- conduct proper listing and certification of waste

- determine the fee for their placement and storage

- provide rationale for the design and determination of landfill locations

- assess the degree of danger to the environment

- assess the danger to human health in the cause of waste handling

- develop differentiated approach in making decisions for reasonable and secure way of waste management - storage, recycling, disposal.

Problems of negative impact of waste on the environment and public health in the places of its formation and accumulation may occur from the moment of formation, at all stages of its handling and up to the moment of disposal or recycling.

In this case, the following risks should be taken into account:

- at the stage of formation

- at the stage of storage (violation of conditions and terms)

- at the stage of transportation (transportation conditions - contact with oxygen, oxidation processes, migration of monomers from polymers)

- at the stage of recycling - use of technologies that do not meet European standards, which can lead to environmental pollution

- obtaining raw materials and products from waste (toxicity indicators)

- the risk of occupational diseases in the process of dealing with waste.

According to the EU Hazardous Waste Directive, "waste is classified as hazardous if it contains certain hazardous chemicals or has properties that can make it hazardous".

When assigning waste to certain classification risk categories according to EU Directives, origin and constituent ingredients, that can make them dangerous, should be taken into account. 
According to the recommendations of the UN there are the following hazard categories of chemicals [5]:

- explosive substances and products

- flammable substances

- flammable solids

- substances prone to spontaneous ignition

- substances that emit flammable gases in contact with water

- oxidizing substances

- organic peroxides

- toxic substances

- infectious substances

- radioactive materials

- corrosive substances

- other dangerous substances and products.

Current European legislation in accordance with Article 2 of the European Commission Decision 2000/532/EC recommends that when assessing the hazard of waste the percentage of one or more of the mentioned components be taken into account, if they are classified as [6,7]:

- potent toxic substances $>0.1 \%$;

- toxic substances $>3.0 \%$;

- hazardous substances $>25.0 \%$;

- caustic substances (symbol - R35) > 1.0\%;

- caustic substances (symbol - R34) $>5.0 \%$;

- irritants (symbol - R41) > 10.0\%;

- irritants (symbols - R36, R37, R38) > $20.0 \%$;

- class 1 or 2 carcinogen $>0.1 \%$;

- class 3 carcinogen $>1.0 \%$;

- substances that exhibit class 1 or 2 reproductive toxicity (symbols - R60, R61) > 0.5\%;

- substances that exhibit class 3 reproductive toxicity (symbols - R62, R63) > 5.0\%;

- class 3 mutagen (symbol - R40) > 1.0\%;

- class 1 or 2 mutagen (symbol - R46) $>0.1 \%$.

SGS SA (Société Générale de Surveillance) is

a Swiss company that provides independent examination, control, testing and certification services (the total number of staff of the Ukrainian division of SGS is 1,200 people) and allows to classify substances by such hazard factors based on known data on dangerous properties of chemicals and mixtures. SGS SA was created to bring the hazard criteria of substances, used in different countries, to a single standard. In complex cases, reliable epidemiological data and information on the effects of substances on humans are taken into account, and in the case of mixtures for which reliable test data may be missing, the method of interpolation of the properties of the components of these mixtures is used. In terms of impact on the human body 9 hazard types as listed above are also defined (according to acute toxicity in a single oral, inhalation or transdermal application).

Based on the analysis of the presence or absence of the above-mentioned toxicity criteria, certain hazard classification category is assigned to the components of the waste. According to the appendix 3 of the Directive on hazardous waste when assessing the danger of waste, ecotoxicity should be among other properties, taken into account. There are two types of hazards for the environment - for the aquatic environment and the ozone layer.

Determination of the environmental hazard of waste allows taking into account both the direct danger of working with it and long-term risks when using different technologies for waste management, disposal or recycling. The presence of hazardous chemicals in human habitats is determined by the state of certain microorganisms most sensitive to each type of pollutants. The toxicity of water, precipitation, wastewater, water extracts from soils is established by the change of the level of fluorescence of chlorophyll, algae cells. When enzyme systems were used as a test object (dehydrogenase inhibition assessment), rather high sensitivity of test reactions to the presence in water of high concentrations of heavy metals (mercury, lead, copper, cadmium) and some organic compounds (phenols, resorcinol, hydroquinone, etc.) was found.

Tetrahymena pyriformis W., as an in vitro test system, is widely used in toxicology as an alternative test object for detecting the toxicity of many environmental pollutants. As a rule, studies on infusoria are performed according to the criterion of "cell death" to determine the parameters of acute and chronic toxicity. In addition to the criterion of "cell death", an important characteristic of the functional state of infusoria is their motor activity [8-12].

The list of some biotests which are conducted with conservation purposes is presented in Table. 1.

At the First Congress of Russian Toxicologists a special workshop was devoted to the reports on alternative methods of study [13]. The use of alternative models in toxicology is recommended in three areas:

- identification of the toxicometry parameters for individual chemicals or mixtures of 
The list of some biotests which are conducted with conservation purposes

\begin{tabular}{|c|c|c|c|c|}
\hline Biotests & Method & $\begin{array}{l}\text { Indicator of toxic } \\
\text { influence }\end{array}$ & $\begin{array}{l}\text { Efficiency } \\
\text { assessment }\end{array}$ & $\begin{array}{c}\text { The period } \\
\text { of an experiment }\end{array}$ \\
\hline $\begin{array}{l}\text { Germination of } \\
\text { barley, oat seeds }\end{array}$ & Visual & $\begin{array}{l}\text { Inhibition of } \\
\text { growth }\end{array}$ & $\begin{array}{c}\% \text { in relation to } \\
\text { control }\end{array}$ & 5-7 days \\
\hline $\begin{array}{l}\text { Microfungus } \\
\text { population }\end{array}$ & Luminescent & $\begin{array}{c}\text { Transformation of } \\
\text { morpho-biological } \\
\text { structure }\end{array}$ & $\begin{array}{l}\text { The degree of } \\
\text { transformation }\end{array}$ & 10-30 days \\
\hline Micromecees fungi & Light microscope & $\begin{array}{c}\text { Germinated spores } \\
\text { counting }\end{array}$ & $\begin{array}{c}\% \text { in relation to } \\
\text { control }\end{array}$ & 10-30 days \\
\hline Microorganisms & $\begin{array}{c}\text { Gas chromatograph } \\
\text { Microscope }\end{array}$ & $\begin{array}{c}\text { Respiratory } \\
\text { intensity. } \\
\text { Viable cell counting }\end{array}$ & $\begin{array}{c}\text { Oxygen } \\
\text { consumption } \% \\
\text { in relation } \\
\text { to control } \\
\end{array}$ & up to 48 hours \\
\hline $\begin{array}{c}\text { Invertebrata } \\
\text { Daphnids (Daphnia } \\
\text { magna Straus) }\end{array}$ & Microscope & Death & ALC & 24-96 hours \\
\hline $\begin{array}{c}\text { Crustacea } \\
\text { (Ceriodaphnia } \\
\text { affinis Zill) }\end{array}$ & Visual counting & Death & $\begin{array}{l}50 \% \text { of deaths } \\
\text { Acute toxicity } \\
\text { effects }\end{array}$ & 48 hours \\
\hline \multirow{2}{*}{$\begin{array}{c}\text { Green algae } \\
\text { Scenedesmus } \\
\text { (Scenedesmus } \\
\text { guadricauda Turp. } \\
\text { Breb) }\end{array}$} & $\begin{array}{l}\text { Microscope or } \\
\text { automatic counting }\end{array}$ & Population growth & $\%$ to control & Up to 30 days \\
\hline & $\begin{array}{l}\text { Laser doppler } \\
\text { spectroscopy }\end{array}$ & $\begin{array}{c}\text { Cell mobility } \\
\text { speed - the parame- } \\
\text { ters of movement } \\
\text { energy expenditure }\end{array}$ & $\begin{array}{l}\text { Motion energy } \\
\text { consumption } \\
\text { values }\end{array}$ & $1.5-2$ minutes \\
\hline \multirow{2}{*}{$\begin{array}{l}\text { Infusoria } \\
\text { Tetrahymena }\end{array}$} & Microscope & $\begin{array}{c}\text { Death, } \\
\text { character } \\
\text { of movement } \\
\text { change }\end{array}$ & $\begin{array}{l}\text { Toxicity of } \mathrm{LC}_{50} \\
\quad \text { (effective } \\
\text { concentrations) }\end{array}$ & $30-60$ minutes \\
\hline & $\begin{array}{l}\text { Laser doppler } \\
\text { spectroscopy }\end{array}$ & $\begin{array}{l}\text { Cell mobility } \\
\text { speed - the parame- } \\
\text { ters of movement } \\
\text { energy expenditure }\end{array}$ & $\begin{array}{l}\text { Motion energy } \\
\text { consumption } \\
\text { values }\end{array}$ & $1.5-2$ minutes \\
\hline
\end{tabular}

products in order to assess their toxicity; - assessment of the degree of toxicity of water, bottom sediments, soils at multifactorial pollution;

- sanitary and toxicological assessment of industrial products, as well as industrial waste, as a stage of their sanitary-epidemiological examination.

The introduction of alternative models and methods in toxicology is supported by WHO and the International biomedical community. It is controlled by international organizations such as the European Centre for the Validation of Alternative Methods (ECVAM), the Interagency Coordinating Committee on the Validation of Alternative Methods (ICCVAM), the European Society of Toxicology In Vitro (ISTIV).

In many sectors of industry, when assessing the toxicity of waste, the amount of animal testing is gradually declining. The reliability of biotesting methods and their compliance with the tasks is coordinated by independent expertise in the fields of biology, chemistry, agrochemistry and pharmaceutics. 
The advantages of biotesting methods are:

- universality, expressivity, simplicity, availability, low cost and high sensitivity;

- efficiency in receiving the answer;

- availability and representativeness of test objects.

The main test objects for the assessment of ecotoxicity are presented in Table 2.

For research purposes, according to the US

Environmental Protection Agency (EPA), 4,650 tests with 145 test objects are performed for hazard assessments of waste.

The following alternative models have currently been developed:

1. Invertebrates

2. Hydrobionts
3. Microorganisms

4. Plants

5. Cultures of human and animal cells

The list of alternative test objects for toxicity assessment is presented in Table 3.

Presented in the literature data on the assessment of toxicity of a number of wastes performed on laboratory animals, as well as with biotesting on Daphnia Magna Straus and Scenedesmus quadricauda methods (Table 4) indicate a significant sensitivity of biotesting methods compared to studies conducted on laboratory animals [14].

Designation of certain categories of waste hazard is a particularly acute issue for Ukraine, firstly, because of the lack of regulatory frame-

Table 2

The main test-objects for the assessment of ecotoxicity

\begin{tabular}{|c|c|c|}
\hline Fish * & Crustacea ** & $\begin{array}{l}\text { Algae and other water } \\
\text { organisms } * * *\end{array}$ \\
\hline $\begin{array}{l}\text { Oncorhynchus mykiss } \\
\text { (rainbow trout); } \\
\text { Pimephales promelas } \\
\text { (fathead minnow - cyprinids); } \\
\text { Danio rerio; } \\
\text { Oryzias latipes } \\
\text { (Japanese rice fish or medaka); } \\
\text { Cyprinodon variegates } \\
\text { (pupfish); } \\
\text { Menidia sp. (Atherinopsidae) }\end{array}$ & Daphnia & $\begin{array}{l}\text { Green algae: } \\
\text { Pseudokirchneriella subcapitata } \\
\text { (Selenastrum capricornutum); } \\
\text { Desmodesmus subspicatus } \\
\text { (Scenedesmus subspicatus). } \\
\text { Diatoms: Navicula pelliculosa. } \\
\text { Green algae (cyanobacteria): } \\
\text { Anabaena flosaguae, } \\
\text { Synechococcus leopoliens. }\end{array}$ \\
\hline
\end{tabular}

Note: * OECD 210 "Fish, Early-life Stage Toxicity Test"

** OECD 202 "Daphnia sp, Acute Immobilization Test", OECD 211 "Daphnia magna Reproduction Test"

*** OECD 201 "Freshwater Alga and Cyannobacteria, Growth Inhibition Test"

Table 3

Alternative test objects for waste toxicity assessment

\begin{tabular}{|c|c|c|c|}
\hline $\begin{array}{c}\text { Assessment } \\
\text { of sensibilisation } \\
\text { effect }\end{array}$ & $\begin{array}{l}\text { Assessment of skin - } \\
\text { irritating effect }\end{array}$ & $\begin{array}{l}\text { Assessment of irritating } \\
\text { effect on mucous } \\
\text { membrane }\end{array}$ & $\begin{array}{l}\text { Assessment of mutagenic effect of } \\
\text { waste and contaminated } \\
\text { environmental objects }\end{array}$ \\
\hline $\begin{array}{l}\text { OECD 442E } \\
\text { "In Vitro Skin } \\
\text { Sensitisation: } \\
\text { In Vitro Skin } \\
\text { Sensitisation } \\
\text { assays addressing } \\
\text { the Key Event on } \\
\text { activation of den- } \\
\text { dritic cells on the } \\
\text { Adverse Outcome } \\
\text { Pathway for Skin } \\
\text { Sensitisation". }\end{array}$ & \begin{tabular}{|c|} 
OECD 431 "In vitro \\
Skin Corrosion: \\
Reconstructed \\
Human Epidermis \\
(RHE) Test \\
Method" \\
OECD 439 "In vitro \\
Skin Irritation: \\
Reconstructed \\
Human Epidermis \\
Test Method"
\end{tabular} & $\begin{array}{l}\text { OECD } 492 \\
\text { "Reconstructed } \\
\text { Human Cornea-like } \\
\text { Epithelium (RhCE) } \\
\text { test method for identi- } \\
\text { fying chemicals } \\
\text { not requiring classifica- } \\
\text { tion and labelling for } \\
\text { eye irritation or serious } \\
\text { eye damage" }\end{array}$ & $\begin{array}{l}\text { OECD } 471 \text { "Bacterial Reverse } \\
\text { Mutation Test" (test objects; } \\
\text { Salmonella typhimurium and } \\
\text { Escherichia coli) } \\
\text { OECD } 476 \text { "In vitro Mammalian } \\
\text { Cell Gene Mutation Test" } \\
\text { OECD } 474 \text { "Mammalian } \\
\text { Erythrocyte } \\
\text { Micronucleus Test" } \\
\text { OECD } 475 \text { "Mammalian Bone } \\
\text { Marrow } \\
\text { Chromosome Aberration Test" }\end{array}$ \\
\hline
\end{tabular}


work, and secondly - because of the mismatch between the EU classification of waste (hazardous, safe, inert) and the Ukrainian one (1-4 classes of danger). The existing so far in Ukraine method of determining waste hazard class for toxicological criteria $\left(\mathrm{LD}_{50}\right.$, the MPC in soil), physico-chemical parameters (volatility and solubility) does not take into account a number of factors of potential danger. Application of this technique for a full-range assessment of environmental risks was impossible. At present, the regulatory document, which determines hazard classes, is put on hold [15]. When assigning the degree of waste hazard the requirements set out in the Resolution of the Cabinet of Ministers № 1120 on the Basel Convention are applied [16]. This document recommends assigning waste to yellow list (dangerous) or green list (safe) taking into consideration the constituent ingredients of waste. Lists of chemicals, developed by the International Organization for Economic Cooperation and Development (OECD) and the list of dangerous properties, are in line with European legislation. However, this classification is made and can be used only for the cross-border transportation of hazardous freight, as the data on the technology of waste production, ingredients and their consistency, storage conditions are often missing.
We have conducted comparative studies of the toxicity of water extracts on some animals at a single intra gastric administration (at an average lethal concentration $-\mathrm{LD}_{50}$ ) and on culture of unicellular Tetrahymena pyriformis W infusoria (death, \%) (Table 5) [17, 18].

The results presented in table. 5 , indicate a possible negative impact on the environment (percentage of infusoria death 5-100\%) of some of the studied wastes (compost after the biodegradation of unfit and banned pesticides (UBP), premixes, black sludge, pyritic sulphur, drill cuttings), which allows to determine them as hazardous wastes. At the same time for these wastes no toxic effect was found in warmblooded organisms at a single intragastric admission and transdermal application [19].

An analysis of the potential danger to the environment and human health of used car oil filters was conducted with the obtained results of their chemical and toxicological features studies. Mixed samples from used filters (oils and material of these filters) extracted from garbage containers at car service stations were used for the research. It is established that used car oils are of low-hazard for warm-blooded animals (hazard class 4 in accordance with GOST (State Standard) 12.1.007-76 at LD $_{50}>$ $5000 \mathrm{mg} / \mathrm{kg}$ ). Signs of irritative effect on skin were not found. However, using the method of

Table 4

Comparative evaluation of the results of research on the toxicity of waste in laboratory animals and with biotesting methods

\begin{tabular}{|c|c|c|c|}
\hline $\begin{array}{c}\text { Test oject } \\
\text { (aqueous extracts) }\end{array}$ & $\begin{array}{c}\text { Toxicity to laboratory } \\
\text { animals* }\end{array}$ & $\begin{array}{c}\text { Daphnia (Daphnia } \\
\text { Magna Straus) death, \% }\end{array}$ & $\begin{array}{c}\text { Green freshwater algae } \\
\text { (Scenedesmus } \\
\text { quadricauda) death, \% }\end{array}$ \\
\hline Sewage sludge & 4 & 50 & 40 \\
\hline Galvanic sludge & 4 & $3-4$ & 30 \\
\hline $\begin{array}{c}\text { Waste, containing oil } \\
\text { and oil products }\end{array}$ & 4 & 20 & 20 \\
\hline $\begin{array}{c}\text { Polymer wastes, } \\
\text { contaminated } \\
\text { with barium carbonate }\end{array}$ & 4 & 30 & $35-64$ \\
\hline $\begin{array}{c}\text { Oil containing medical } \\
\text { waste }\end{array}$ & $3-4$ & $14-30$ & 20 \\
\hline $\begin{array}{c}\text { Water-soluble medical } \\
\text { waste }\end{array}$ & $3-4$ & 15 & $98-100$ \\
\hline Mixture of medicines & Not performed & $95-100$ & \\
\hline
\end{tabular}

Note: * DSanPin 2.2. 7.029-99 [15] 
The results of comparative studies of waste toxicity on Tetrahymena pyriformis $\mathrm{W}$ infusoria and laboratory animals

\begin{tabular}{|c|c|c|c|}
\hline Test object & $\begin{array}{c}\text { Toxicity to laboratory } \\
\text { animals * }\end{array}$ & Irritating effect & $\begin{array}{c}\text { Toxicity to Tetrahymena } \\
\text { pyriformis W ** }\end{array}$ \\
\hline $\begin{array}{c}\text { Compost after the } \\
\text { biodegradation of chlor } \\
\text { organic pesticides }\end{array}$ & Moderate hazard & No & 100 \\
\hline Pyritic sulphur & Low hazard & No & 100 \\
\hline Black sludge & Low hazard & No & 6 \\
\hline $\begin{array}{c}\text { Sand and oil contami- } \\
\text { nated algae mixture }\end{array}$ & Low hazard & No & 30 \\
\hline $\begin{array}{c}\text { Premixes - mixtures of } \\
\text { wastes of undefined } \\
\text { composition }\end{array}$ & Low hazard & No & 5 \\
\hline Drill cuttings & Low hazard & No & \\
\hline
\end{tabular}

Note: * - GOST 12.1.007-76 (State standard) [19]

** - infusoria $-\%$ of death

biotesting, in the test for induction of chromosome aberrations in culture of human peripheral blood lymphocytes in vitro in experimental variants with and without metabolic activation a mutagenic activity of oil from used car filters was revealed [20, 21].

Systematic dumping of this waste in landfills and dumps, when chemical processes take place under the influence of environmental factors (acidity, moisture, temperature, solar insolation) will facilitate the migration of toxic substances into ecosystems and cause negative effects for the environment and the population living in the surrounding areas. The threat of pollution and negative impact on groundwater and surface water is quite high. The above mentioned data allowed us to consider used car filters as toxic wastes, which requires, when working with them, stricter regulation in terms of collection and disposal, as well as control by the state.

The results of the research confirm the effectiveness of biotesting methods in assessing the hazardousness of waste in comparison to traditional chemical-analytical approaches in assessing the degree of pollution of ecosystems, which is consistent with European approaches to assessing the risks of pollutants to humans and their habitats.
Conclusions. 1. One of the priority areas of approximation to the requirements of the European Union on waste management is the harmonization of modern Ukrainian legislation with European standards, adaptation of regulations, in particular on production wastes and consumption residue.

2. An essential issue in the implementation of state waste management system in Ukraine is the development and implementation of directives on the methodology of assigning waste to a certain classification category by hazard, taking into account current WHO recommendations and European Directives on waste management.

3. Assignment of waste to certain classification categories for toxicity and danger for the environmental and public health should be based not only on quantitative calculations of the chemical composition of their hazardous chemical components, but also on biological experimental testing of samples.

4. The principles of wastes risk assessment methodology are:

- Integral assessment of total waste hazard resulting from contamination of all contacting environments; 
- Comprehensive assessment of the waste as a single dangerous agent, inclusive of the dynamics and forms of its transformation in the environment;

- Consideration of the specific harmful effects of waste in each environment contacting with the human;
- Evaluation of waste constituent ingredients that defines the nature of their dangerous action.

5. Experimental determination of the degree of waste danger - a laboratory testing of the environmental toxicity of studied samples with the use of biological objects.

\section{REFERENCES}

1. Hardashuk TV. Povodzhennia z vidkhodamy yak hlobalna problema. Materialy Natsionalnoho forumu «Povod-zhennia z vidkhodamy v Ukraini: zakonodavstvo, ekonomika, tekhnolohii»; Kyiv, 2016.

2. Nikulichev YuV. Upravlenie otkhodami. Opy`t Evropejskogo soyuza. Analit. obzor RAN. INION. Czentr nauch.-inform. issled. glob. i regional. probl. Otd. prob. evrop. bezopasnosti. M; 2017. 55 s.

3. Poviakel LI, Snoz SV, Smerdova LM, Kryvenchuk VIe. Novi pidkhody u sferi povodzhennia $\mathrm{z}$ vidkhodamy $\mathrm{v}$ Ukraini u zviazku z implementatsiieiu pryrodookhoronnykh dyrektyv Yevropeiskoho soiuzu do vitchyznianoho zakonodavstva. Suchasni problemy toksykolohii, kharchovoi ta khimichnoi bezpeky. 2016; 1: 5-12.

4. Rozporiadzhennia Kabinetu Ministriv Ukrainy «Pro implementatsiiu Uhody pro asotsiatsiiu mizh Ukrainoiu, z odniiei storony, ta Yevropeiskym soiuzom, Yevropeiskym spivtovarystvom $\mathrm{z}$ atomnoi enerhii $\mathrm{z}$ inshymy derzhavamy $\mathrm{z}$ inshoi storony» № 847-r vid 17.09.2014.

5. ADR (European Agreement concerning the International Carriage of Dangerous Goods by Road), applicable since 1 January 2017. United Nations, 2017. https://unece.org/DAM/ trans/danger/publi/adr/adr2017/ADR2017E_web.pdf

6. Commission Decision 2000/532/EC replacing Decision 94/3/EC establishing a list of wastes pursuant to article 1(a) of Council Directive 75/442/EEC on waste and Council Decision 94/904/EC establishing a list of hazardous waste pursuant to article 1(4) of Council Directive 91/689/EEC on hazardous waste. Official Journal L 226 , 06/09/2000, 0003-24.

7. Council Directive 91/689/EEC of 12 December 1991 on hazardous waste. Official Journal L 377, 31/12/1991, 0020-7.

8. Es`kov AP, Kayumov RI, Sokolov AE. Toksikologicheskie ispy`taniya. Al’ternativny`e metody`. Toksikologicheskij vestnik. 2003; 5: 25.

9. Trakhtenberg IM, Kovalenko VM, Kokshareva NV. Al'ternativny`e metody' i test-sistemy'. Monografiya K: Aviczenna; 2008. 272 s.

10. Kazantsev AG. Method and control devices for aquatic toxicity test reaction dynamics galvanotaxis ciliates P.CAUDATUM. Dis. Those candidate Sciences. St. Petersburg; 2010. P. 13.

11. Puzakov AV, Neumoina AA, Isaeva SV, Safronova LA. Opredelenie klassa opasnosti mediczinskikh otkhodov metodom biotestirovaniya. Mat. Vseros. nauch.-prakt. kon- ferenczii. E’kologiya: sintez estestvennonauchnogo, tekhnicheskogo i gumanitarnogo znaniya; 2010 oktyabrya 19-22; Saratov; 167-8.

12. Kompleksnaya biologicheskaya oczenka ob`ektov prirodnogo i iskusstvennogo proiskhozhdeniya na Tetrahymena Pyriformis W. Metodicheskie rekomendaczii. Minsk; 1996. 19 s.

13. Korshun MN. Teoreticheskie i prikladny'e aspekty' ispol'zovaniya biologicheskikh modelej vtorogo poryadka v toksikologo-gigienicheskikh issledovaniyakh. Sovremenny`e problemy` toksikologii. 2007; 3: 66-7.

14. Safronova LA, Yuferova EV. Metody` biotestirovaniya dlya opredeleniya klassa opasnosti otkhodov. Byulleten` mediczinskikh Internet-konferenczij. 2012; 4(2): 217-8.

15. DSanPiN 2.2.7.029-99 «Hihiienichni vymohy shchodo povodzhennia z promyslovymy vidkhodamy ta vyznachennia yikh klasu nebezpeky dlia zdorovia naselennia».

16. Postanova Kabminu Ukrainy vid 13 lypnia 2000 r. №1120 «Pro zatverdzhennia Polozhennia pro kontrol za transkordonnymy perevezenniamy nebezpechnykh vidkhodiv ta yikh utylizatsiieiu/vydalenniam i Zhovtoho ta Zelenoho perelikiv vidkhodiv»».

17. Zhmin `ko PG, Yankevich MV, Gerasimova VG, Ly`senko KO, Zhmin`ko OP. «Metodika e`kspressnogo biotestirovaniya khimicheskikh veshhestv, sinteticheskikh materialov khozyajstvennogo, by tovogo i mediczinskogo naznacheniya i oczenki ikh opasnosti dlya cheloveka» Reestr otraslevy’kh novovvedenij vy’p. 14-15, 2001, №45/14/01.

18. Kasparov AA, Sanoczkij IV. Toksikometriya khimicheskikh veshhestv, zagryaznyayushhikh okruzhayushhuyu sredu. Moskva; 1986. $428 \mathrm{~s}$.

19. GOST 12.1.007-76 «Sistema standartov bezopasnosti truda. Vredny`e veshhestva. Klassifikacziya i obshhie trebovaniya bezopasnosti».

20. Boltina IV, Povyakel LI. Svidotstvo na reiestratsiiu avtorskykh prav na tvir №23793 vid 05.03.2008 r. «Primenenie testa na indukcziyu aberraczij khromosom v kul ture limfoczitov perifericheskoj krovi cheloveka pri issledovanii mutagennogo e'ffekta promy'shlenny'kh i by 'tovy'kh otkhodov»».

21. Povyakel' LI, Krivenchuk VE, Smerdova LN, Zhmin 'ko OP, Boltina IV, Kostik EL i dr. Otrabotanny`e avtomobil'ny`e maslyany`e fil’try' kak istochniki opasny`kh otkhodov. Sovremenny`e problemy` toksikologii. 2005; 4: 11. 


\section{МЕТОДИЧНІ ПРИНЦИПИ ВІДНЕСЕННЯ ВІДХОДІВ ДО ПЕВНӦ̈ КЛАСИФІКАЦІЙНОЇ КАТЕГОРЇ̈ ЩОДО НЕБЕЗПЕКИ}

Л.І. Повякель, О.П. Васецька, Г.І. Петрашенко, О.О. Бобильова, В.С. Кривенчук, О.С. Зубко

ДП «Науковий центр превентивної токсикології, харчової та хімічної безпеки імені академіка Л.І. Медведя МОЗ

України», м Київ, Україна

PЕЗЮМЕ. Мета. Обгрунтувати підходи з'ясування проблеми оцінки негативного впливу відходів на здоров'я населення та навколишнє середовище, який виникає з моменту утворення і на всіх етапах поводження з відходами.

Матеріали та методи. Одним з пріоритетних напрямків наближення до вимог Свропейського Союзу при поводженні з відходами є гармонізація сучасного українського законодавства до європейських стандартів, адаптація положень нормативно-правових актів, у тому числі класифікація відходів за ступенем небезпеки. У статті проводиться порівняльний аналіз законодавчої бази з оцінки небезпеки відходів існуючої в даний час в Україні з рекомендаціями ВООЗ та Директивами СС. Обгрунтовані і рекомендовані для впровадження методичні принципи віднесення відходів до певної класифікаційної категорії за небезпекою.

Результати та висновки. Науково обтрунтовано, що віднесення відходів до певної класифікаційної категорії за небезпекою повинно грунтуватися не тільки на кількісних розрахунках за хімічним складом і токсичності складових інгредієнтів, які входять до складу відходів, а й на експериментальній перевіриі зразків з використанням альтернативних методів.

Ключові слова: відходи, Директиви СС, класифікація, біотестування, токсичність, небезпека, альтернативні методи.

\section{МЕТОДИЧЕСКИЕ ПРИНЦИПЫОТНЕСЕНИЯ ОТХОДОВ К ОПРЕДЕЛЕННОЙ КЛАССИФИКАЦИОННОЙ КАТЕГОРИИ ПО ОПАСНОСТИ}

Л.И. Повякель, О.П. Васецкая, А.И. Петрашенко, О.А. Бобылева, В.Е. Кривенчук, Е.С. Зубко

ГП «Научный центр превентивной токсикологии, пищевой и химической безопасности имени академика Л.И. Медведя МЗ Украины», г. Киев, Украина

PЕЗЮМЕ. Цель. Обосновать подходы к решению проблемы оценки негативного действия отходов на здоровье населения и окружающею среду, которое возникает с момента образования и на всех этапах обращения с отходами.

Материалы и методы. Одним из приоритетных направлений приближения к требованиям Европейского союза при обращении с отходами является гармонизация современного украинского законодательства с европейскими стандартами, адаптация положений нормативно-правовых актов, в том числе классификация отходов по степени опасности. $B$ статье проводится сравнительный анализ законодательной базы по оценке опасности отходов существующей в настоящее время в Украине с рекомендациями ВОЗ и Директивами ЕС. Обоснованы и рекомендованы для внедрения методические принципы отнесения отходов к определенной классификационной категории по опасности.

Результаты и выводы. Научно обосновано, что отнесение отходов к определенной классификационной категории по опасности должно основываться не только на количественных расчетах по химическому составу и токсичности составляющих ингредиентов, которые входят в состав отходов, но и на экспериментальной проверке образиов с использованием альтернативных методов.

Ключевые слова: отходы, Директивы ЕС, классификация, биотестирование, токсичность, опасность, альтернативные методы.

Received 09/24/2020 